\title{
Occurrence of Perkinsus olseni (Protozoa: Apicomplexa) and other parasites in the venerid commercial clam Pitar rostrata from Uruguay, southwestern Atlantic coast
}

\author{
Florencia Cremonte $^{1, *}$, Pablo Balseiro ${ }^{2}$, Antonio Figueras ${ }^{2}$ \\ ${ }^{1}$ Centro Nacional Patagónico (CONICET), Boulevard Brown s/no 9120 Puerto Madryn, Chubut, Argentina \\ ${ }^{2}$ Instituto de Investigaciones Marinas (CSIC), Eduardo Cabello 6, 36208 Vigo, Spain
}

\begin{abstract}
A study was conducted into the health status of natural populations of the venerid clam Pitar rostrata from Uruguay. Perkinsus sp. was detected in $22 \%$ of the clams. Severe hemocytic infiltration was detected in the tissues parasitized by this protozoan parasite. The sequencing of the ITS-5.8S gene cluster of the parasite confirmed that it belonged to the Perkinsus olseni species. Rickettsia or Chlamidia-like organisms were also found, with a prevalence of $11 \%$, although without apparent host reaction; an unidentified species of Coccidia was found in the nephridia of $78 \%$ of the clams, with the intensity of infection ranging from moderate to high. A gregarine, Nematopsis-like organism was observed mainly in the epithelial cells of the intestine, without host response and with a prevalence of $56 \%$. Of the metazoan parasites, trematodes were found in $11 \%$ of the individuals analyzed.
\end{abstract}

KEY WORDS: Perkinsus olseni · Pathology $\cdot$ Pitar rostrata $\cdot$ Venerid clam $\cdot$ Southwestern Atlantic coast

\section{INTRODUCTION}

To date, very little is known about the health status and parasites of South American bivalves (Lauckner 1983, Bower et al. 1994). This situation could be due in part to the fact that molluscan aquaculture is poorly developed on the coasts of the southwestern Atlantic. Moreover, the commercialization of bivalves is, in general, limited to the internal market. However, the increasing demand for fish products in the world, predicts a development of the aquaculture and increased exportation. These factors make it important to know the health status of the commercial bivalves of that region.

The venerid clam Pitar rostrata (Koch, 1844) is distributed in infra and circalittoral sandy beds from Rio de Janeiro in Brazil to the tip of South America (Scarabino 1977). On the Uruguayan coast, where the fishery of this clam began $3 \mathrm{yr}$ ago, the clams are harvested with trawl nets at a depth of $30 \mathrm{~m}$ (G. Riestra, Dirección Nacional de Recursos Acuáticos in Montevideo, Uruguay, pers. comm.). There is no information about the biology and ecology of $P$. rostrata, but initial studies are being conducted (G. Riestra pers. comm.). This venerid clam was reported as a potential resource in other countries, including Argentina (Lasta et al. 1998). The Uruguayan companies that exploit this clam are interested in exporting it as a fresh product to Europe, and it is this interest which stimulated the present parasitological survey.

Protozoan parasites of the genus Perkinsus infect a great number of molluscan species around the world. Perkinsus marinus (Mackin et al. 1950) is the causative agent of 'Dermo' disease in Crassostrea virginica and is responsible for significant mortalities (Lauckner 1983). P. marinus is a pathogen included in the OIE 
(Office International des Epizooties) list of notifiable diseases; it is found along the east coast of the United States from Maine to Florida, along the Gulf coast to Venezuela, in Puerto Rico, Cuba, and Brazil, and was accidentally introduced in Hawaii (Bower et al. 1994). Other species described more recently were $P$. olseni in the gastropod Haliotis ruber from Australia (Lester \& Davis 1981), P. atlanticus in the carpet-shell clam Ruditapes decussatus (Azevedo 1989), P. karlssoni in Argopecten irradians (McGladdery et al. 1991), P. qugwadi in Patinopecten yessonesis (Blackbourn et al. 1998), P. chesapeaki (McLaughlin et al. 2000) in Mya arenaria and $P$. andrewsi in Macoma balthica (Coss et al. 2001). P. karlssoni is no longer considered to be a valid species. Thus, the identity of the pathogen that caused the disease in Argopecten irradians in Atlantic Canada and eastern USA remains unknown (Goggin et al. 1996). The possibility of synonymy between $P$. chesapeaki and P. andrewsi (Dungan et al. 2002) and between $P$. olseni and $P$. atlanticus based in the homology found in the nontranscribed regions of the rRNA cluster has also been postulated (Goggin 1994, Murrell et al. 2002). P. olseni, the first described species, has a great number of hosts including the abalones (gastropods) Haliotis ruber, $H$. laevigata, $H$. cyclobates in South Australia and the clams Ruditapes decussatus, Venerupis aurea, Tapes philippinarum in Portugal, Spain, France, and also in Japan and Korea (Bower et al. 1994, Hamaguchi et al. 1998). Moreover, Perkinsus spp. can infect different families of marine bivalves around the world (Goggin \& Lester 1987).

The internal transcribed spacers (ITS-1 and ITS-2) are non-coding regions of the RNA gene cluster that are less conserved than the ribosomal RNA coding genes; this make them more suitable to distinguish among proximal species. Sequences of the ITS-1, 5.8S and ITS-2 region of the ribosomal RNA operon have been used in several studies to distinguish different species of the genus Perkinsus (Kotob et al. 1999, Robledo et al. 1999, 2000, Casas et al. 2002a,b, Dungan et al. 2002). These authors pointed out for first time the similarity among $P$. olseni from abalones (Haliotis ruber) from Australia, P. atlanticus from carpet-shell clam Ruditapes decussatus from Portugal and 2 other Perkinsus species, 1 from the jewel box Chama pacificus and the other from the blood cockle Anadara trapezia, both from Australia (Goggin 1994).

\section{MATERIALS AND METHODS}

Samples. Two samplings of the clam Pitar rostrata were made on the Uruguayan coast in September 2002. The first sample was examined by light microscopy and the second by molecular biology. The samples were subsequently examined at the Instituto de Investigaciones Marinas, Vigo, Spain.

Histopathological analysis. Only 9 clams from the first sample arrived in Spain in good enough condition for microscopic examination. The soft parts of these specimens were carefully removed from their shells and fixed in Davidson's solution (Shaw \& Battle 1957 ) for $24 \mathrm{~h}$. Oblique transverse sections, approximately $5 \mathrm{~mm}$ thick and including mantle, gills, gonad, digestive gland, nephridia, and foot were taken from each specimen. Tissue samples were embedded in paraffin and $5 \mu \mathrm{m}$ sections were stained with hematoxylin and eosin. Histological sections were examined under light microscopy for the presence of parasites and pathological alterations. Histological sections of parasitized clams were deposited in the Protozoological Collection of the Museo de La Plata (MLP Nos. 018 to 020), Museo de La Plata, La Plata, Argentina, and the shells of the clams in the Malacological Collection (MLP No. 6936-1) of the same institution.

Perkinsus sp. specific diagnosis. In a second sampling, the gill tissues of 48 clams were subjected to a molecular analysis to determine specifically the presence of Perkinsus sp. parasites. Genomic DNA was extracted using DNAzol (Invitrogen) following the manufacturer's instructions. The first amplification of the ITS region of the Perkinsus sp. parasites was carried out according to Kotob et al. (1999) in a volume of $25 \mu \mathrm{l}$ with $2.5 \mu \mathrm{l}$ of Buffer 10X (10 mM Tris, $50 \mathrm{mM} \mathrm{KCl}$ (pH 8.3); $2.5 \mathrm{mM} \mathrm{MgCl}_{2} ; 0.2 \mathrm{mM}$ of each dNTP; $0.2 \mu \mathrm{M}$ of each primer, $1 \mu$ l of DNA and $1.25 \mathrm{U}$ of Taq polymerase. The primers used were Perk-ITS S (5'-CTTAGAGGAAGGAGAAGTCGTAAC-3') and Perk-ITS As (5'-GCTTACTTATATGCTTAAATTCAG-3'). After amplification (1 cycle at $94^{\circ} \mathrm{C}$ for 4 min and 42 cycles of: $94^{\circ} \mathrm{C}$ for $1 \mathrm{~min} 11 \mathrm{~s}, 50^{\circ} \mathrm{C}$ for $1 \mathrm{~min} 22 \mathrm{~s}$; and $72^{\circ} \mathrm{C}$ for $1 \mathrm{~min} 11 \mathrm{~s}$; and a final extension step at $72^{\circ} \mathrm{C}$ of $10 \mathrm{~min})$, a nested PCR reaction was conducted using internal primers Pk-ITS1 S (5'-TCTGCGAAACTAGCGGTCTT- ${ }^{\prime}$ ) and Pk-ITS2 As (5'-ACCGACAAGCGTGCTATGAT-3') designed from Perkinsus sp. sequences published in the GenBank. The reaction mixtures consisted in $2.5 \mu \mathrm{l}$ of Buffer $10 \mathrm{X}$ resulting in $10 \mathrm{mM}$ of Tris, $50 \mathrm{mM} \mathrm{KCl} \mathrm{(pH} \mathrm{8.3);} 2 \mathrm{mM} \mathrm{MgCl}_{2}$, $0.16 \mathrm{mM}$ of each dNTP, $0.16 \mu \mathrm{m}$ of each primer, $1 \mathrm{ml}$ of DNA and $1.25 \mathrm{U}$ of Taq polymerase. The following program was used: 1 cycle at $95^{\circ} \mathrm{C}$ for $5 \mathrm{~min}, 35$ cycles at $94^{\circ} \mathrm{C}$ for $1 \mathrm{~min} 30 \mathrm{~s}, 50^{\circ} \mathrm{C}$ for $1 \mathrm{~min} 30 \mathrm{~s}$ and $72^{\circ} \mathrm{C}$ for $1 \mathrm{~min} 30 \mathrm{~s}$ with a final extension for $10 \mathrm{~min}$. PCR products were resolved in $1 \%$ agarose in TAE buffer gel (w/v) stained with ethidium bromide, with a standard size of $100 \mathrm{pb}$ (pair bases) (Invitrogen).

Sequencing. The PCR products (from at least 3 different clam specimens) were purified by enzymatic 
treatment with $10 \mathrm{U}$ of the enzyme Exonuclease I (Exo I) and $1 \mathrm{U}$ of Shrimp Alkaline Phosphatase (SAP) (USB Corporation) for $1 \mathrm{~h}$ at $37^{\circ} \mathrm{C}$ and $15 \mathrm{~min}$ at $80^{\circ} \mathrm{C}$ and sequenced (at least 3 different clones in both upstream and downstream senses) in an ABI Prism 377 DNA sequencer (Applied Biosystems) and aligned in CLUSTALX (Thompson et al. 1997). The sequence obtained was compared using BLAST with those previously published (Altschul et al. 1990).

\section{RESULTS}

The examination of the histological sections revealed the occurrence of several potential pathogens, including bacterial, protistan, and metazoan organisms. A total of 3 protistan species were detected: 1 unidentified coccidian, Nematopsis-like organisms, and a Perkinsus sp. Rounded basophilic colonies of intracellular bacteria (Rickettsiae or Chlamydiae) were observed within the epithelial cells of the digestive gland (Fig. 1). These organisms were found in 1 of the 9 histologically examined clams (prevalence of $11 \%$ ), which presented a heavy infection (201 colonies in the histological section). The diameter of the bacterial colonies ranged from 9 to $32 \mu \mathrm{m}$ with a mean of
$17.90 \mu \mathrm{m}(\mathrm{N}=40)$. There was no obvious defense response to this parasite and no hypertrophy of the infected digestive tubule cells, although those containing the larger colonies were disrupted.

Coccidia of an unidentified species were present in 7 of the 9 examined clams (prevalence of $78 \%$ ). The main parasitized organ was the nephridia, where the parasite stages most frequently observed were large, mature and crescent-shaped macrogamonts, and both mature and immature meronts containing merozoites (Figs. 2 \& 3). The intensity of infection was generally moderate to high. The parasites were detected internally in hypertrophied nephridial epithelial cells and in the lumina of the nephridial tubules which, in heavy infections, were obstructed by parasites and hemocytes. In heavy infections, a few macrogamonts were also seen in the connective tissue that surrounds the intestine.

Oocysts containing 1 uninucleate vermiform sporozoite similar in morphology to Nematopsis spp. were observed mainly in the epithelial cells of the intestine (Fig. 4). The oocysts of this gregarine protozoan were pyriform in shape and measured 21 (19 to 23) $\mu \mathrm{m}$ in length and 14 (11 to 17$) \mu \mathrm{m}$ in width $(\mathrm{N}=30)$. They presented a thick hyaline wall and contained only 1 'worm-like' sporozoite (Figs. 4 \& 5). This protozoan

Figs. 1 to 5. Pitar rostrata. Histological sections (hematoxylin and eosin [H \& E] stain). Fig. 1. Colonies of Rickettsia or Chlamydia-like organisms (arrow) in the cytoplasm of epithelial cells of the digestive tubules, scale bar $=50 \mu \mathrm{m}$. Fig. 2. A nephridial tubule obstructed by different stages of an unidentified Coccidia, scale bar $=40 \mu \mathrm{m}$. Fig. 3 . Macrogamonts (g), immature (im) and a mature meront containing merozoits (m) of an unidentified Coccidia parasite in nephridial tubules, scale bar $=20 \mu \mathrm{m}$. Fig. 4. Intestine epithelium parasitised by oocysts of a Nematopsis-like organism, scale bar $=40 \mu \mathrm{m}$. Fig. 5. Detail of 1 'worm-like' sporozoite (s) inside an oocyst with a thick hyaline wall (w) of a Nematopsis-like organism, scale bar $=5 \mu \mathrm{m}$
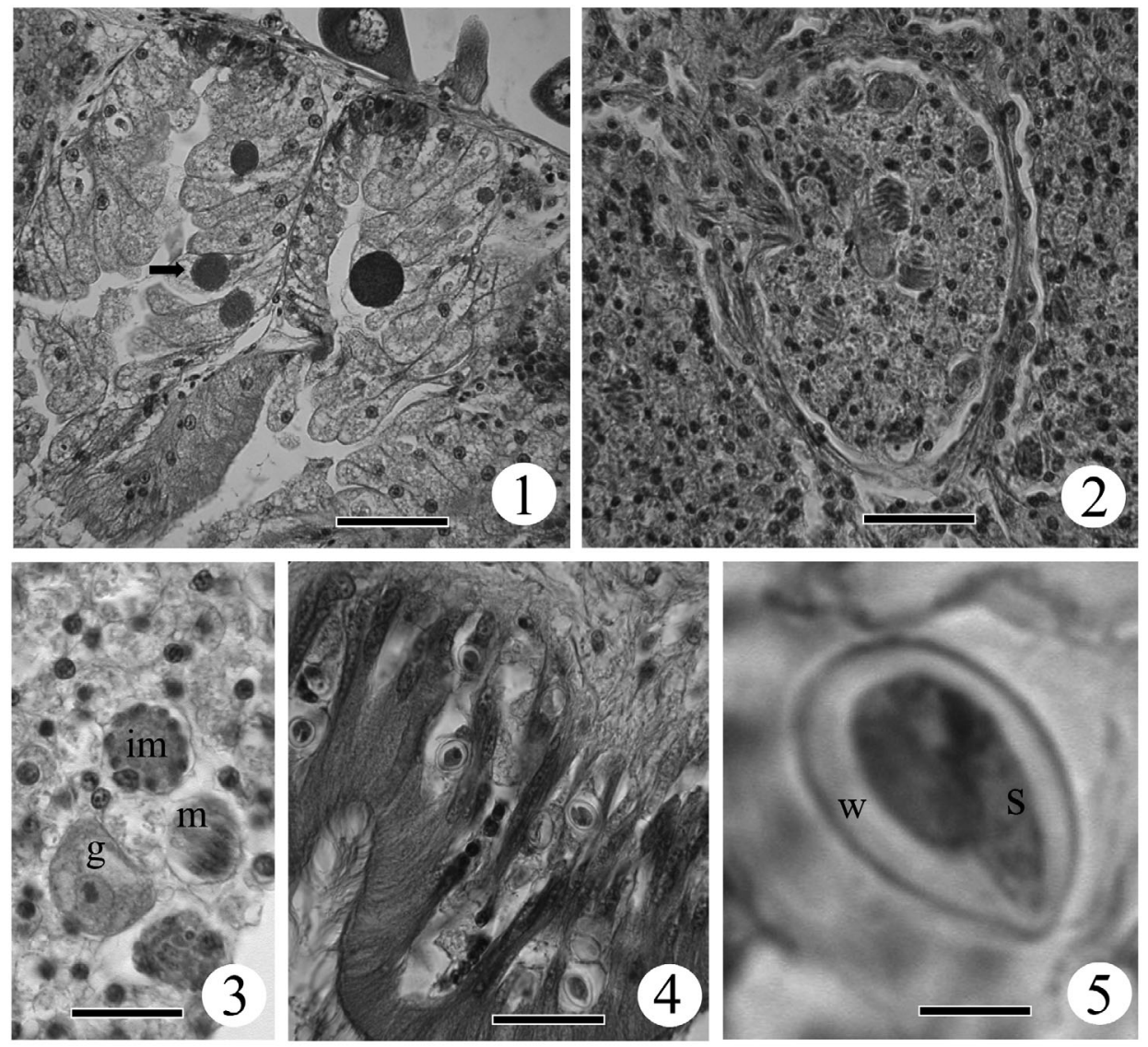
parasite was present in $56 \%$ of the clams, with a moderate intensity of infection. Histopathological signs of host reaction were not detected even in the highest intensity observed.

The trophozoites of Perkinsus sp. were observed mainly in clusters from 7 to 29 individuals (average of $15, \mathrm{~N}=6$ ) in the connective tissue that surrounds the intestinal tubules, as well as in the mantle and gills (Figs. 6 to 8). These trophozoites presented the typical 'signet-ring' shape with a large eccentric vacuole that displaces the nucleus to the periphery of the cell, and measured 18.56 (10 to 31) $\mu \mathrm{m}$ in diameter $(\mathrm{N}=45)$ (Fig. 6). Often the clusters of trophozoites were encapsulated or embedded in amorphous eosinophilic material and tissue debris, forming cyst-like structures (Fig. 7). This protozoan parasite induced a strong host response, with an infiltration of numerous hemocytes into the surrounding tissue (Fig. 8).

In one clam, an encysted metacercaria (Trematoda: Digenea) was found in the connective tissue of the mantle (prevalence of $11 \%$ ). This metazoan parasite, measuring $150 \mu \mathrm{m}$ in diameter, presented a strong spinose tegument. A slight hemocytic response was observed (Fig. 9).
In the second sampling of clams, a PCR product of the expected size (826 pb) for the ITS-5.8S region of Perkinsus sp. appeared in 13 of the 48 clams examined. Furthermore, a band of about 1500 pb was observed corresponding to the host clam; this was confirmed by sequencing. A nested PCR was designed and gave an expected product of $673 \mathrm{pb}$. Several of these PCR products were sequenced and submitted to BLAST. The highest similarity score corresponded to Perkinsus olseni with a $99 \%$ identity (1204 score). The GenBank accession number is AY435092.

Examination by light microscopy showed the prevalence of Perkinsus olseni infection to be $22 \%$ whereas PCR analysis gave a result of $27 \%$.

\section{DISCUSSION}

This study characterises parasites from the venenid clam Pitar rostrata for the first time. Only Nematopsis sp. and Perkinsus sp. parasites had previously been reported from bivalves in the southwest Atlantic Ocean (Lauckner 1983). Perkinsus marinus was reported from Crassostrea virginica in Brazil (Bower et al. 1994).
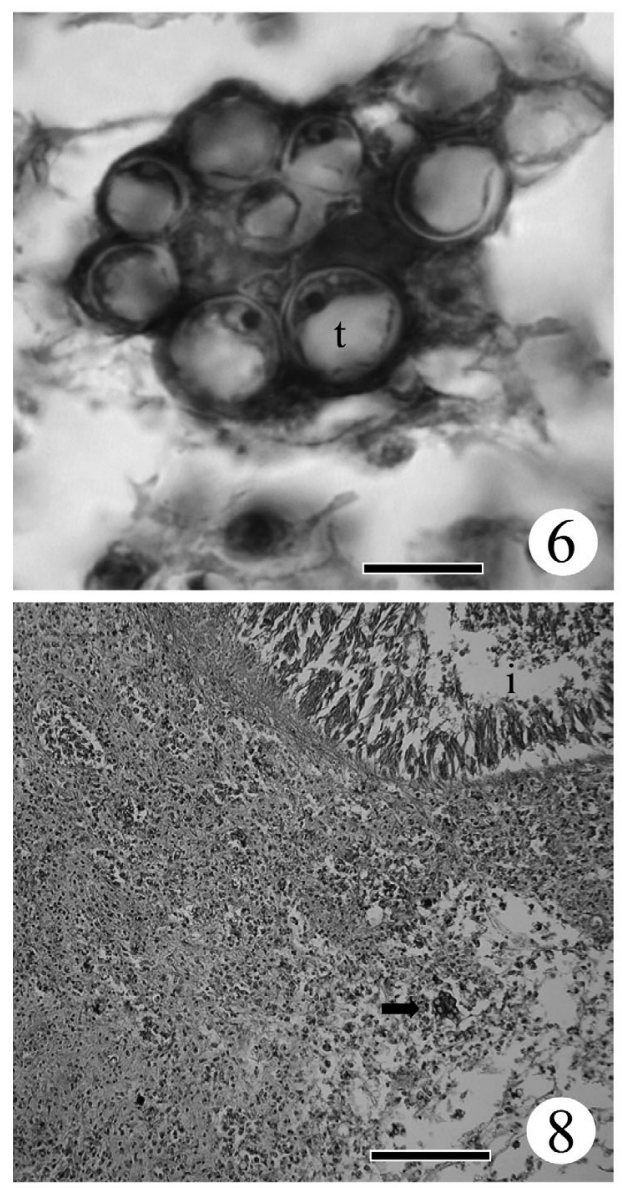

Figs. 6 to 9. Pitar rostrata. Histological sections (H\&E stain). Fig. 6. A cluster formed by several 'signet-ring'-shaped trophozoites (t) of Perkinsus olseni, scale bar $=20 \mu \mathrm{m}$. Fig. 7. Cystlike structure formed in response to the presence of trophozoites (t) of Perkinsus olseni, scale bar $=50 \mu \mathrm{m}$. Fig. 8 . Strong hemocytic infiltration response in the connective tissue that surrounds the intestine (i) caused by the presence of trophozoites of Perkinsus olseni (arrow), scale bar $=1 \mathrm{~mm}$. Fig. 9. Digenetic metacercariae encysted in the connective tissue of the mantle; see tegumental spines (arrow head) and metacercarial cyst (arrow), scale bar $=500 \mu \mathrm{m}$ 
Protozoan parasites of the genus Perkinsus infect a great number of molluscan species, specially bivalves, in several parts of the world; they are responsible for many massive mortalities (Lauckner 1983). In Pitar rostrata, the sequencing of the ITS1-5.8S-ITS2 determined that this sequence belongs to Perkinsus olseni. The prevalence of $P$. olseni in $P$. rostrata seems to be high, since it was found in $22 \%$ of the clams from natural beds by light microscopy, and in $27 \%$ when the PCR test was employed. This is the first report of $P$. olseni from South America and the first report of this protozoan genus in the clam $P$. rostrata.

Rickettsia-like and Chlamydia-like organisms are globally distributed and are parasitic of a wide variety of bivalves (Bower et al. 1994). Frequently, these infections appear to evoke little host response or pathological effect, although some infections may cause clinical diseases, and have been associated with high mortalities (Buchanan 1978, Elston 1986, Villalba 1999). Colonies are mostly found inside the cytoplasm of the digestive tubule epithelial cells without signs of host response, as was observed in Pitar rostrata.

Gregarines of the genus Nematopsis utilize marine bivalves, including venerid clams, as normal intermediate hosts (Lauckner 1983). Although each species may have a confined distribution, they are probably ubiquitous; gregarines are found in the connective tissue of most organs, although they are more frequently observed in gills (Bower et al. 1994). The present case, oocysts parasitizing mainly the intestinal epithelium of Pitar rostrata, is not common.

Unidentified species of Coccidia have been reported in the nephridial tubules of mussels, oysters, scallops, and several clams, including venerids such as Tapes spp. and Protothaca staminea. Their geographical distribution includes the west coast of the United States and Canada, France, the Mediterranean Sea and Scotland (Bower et al. 1994). The present is the first record from South America. The infected nephridial epithelial cells become hypertrophied and kidney tubules fill with coccidia. Heavy infections may cause serious nephridia damage and the parasite can spread to other organs (Morado 1984), as was found in the present study.

Regarding the metacercaria which we found, it should be noted that larval trematodes are the main metazoan parasites of bivalves, although they generally have little or no negative effect on their host (Lauckner 1983, Bower et al. 1994).

Acknowledgements. We thank Iva Dyková for her help in identifying the coccidian stages, Begoña Villaverde and Susana Otero for their technical assistance, Gustavo Riestra for providing the available data on $P$. rostrata in Uruguay and Beatriz Novoa for her valuable comments on the manuscript. We also thank the two anonymous reviewers whose com- ments improved the manuscript. F.C. belongs to Consejo Nacional de Investigaciones Científicas y Técnicas and is grateful to Harengus S.A., Consejo Nacional de Investigaciones Científicas y Técnicas (CONICET) (PIP 2714), and the Agencia Nacional de Promoción Científica y Tecnológica (ANPCyT) (PICT 01-11902) for their partial financial support.

\section{LITERATURE CITED}

Altschul SF, Gish W, Miller W, Myers EW, Lipman DJ (1990) Basic local alignment search tool. J Mol Biol 215:403-410

Azevedo C (1989) Fine structure of Perkinsus atlanticus n. sp. (Apicomplexa, Perkinsea) parasite of the clam Ruditapes decussatus from Portugal. J Parasitol 75:627-635

Blackbourn J, Bower SM, Meyer GR (1998) Perkinsus qugwadi sp. nov. (incertae sedis), a pathogenic protozoan parasite of Japanese scallops, Pectinopecten yessoensis, cultured in British Columbia, Canada. Can J Zool 76:942-953

Bower SM, McGladdery SE, Price IM (1994) Synopsis of infectious diseases and parasites of commercially exploited shellfish. Annu Rev Fish Dis 4:1-199

Casas SM, La Peyre JF, Reece KS, Azevedo C, Villalba A (2002a) Continuous in vitro culture of the carpet shell clam Tapes decussatus protozoan parasite Perkinsus atlanticus. Dis Aquat Org 52:217-231

Casas SM, Villalba A, Reece KS (2002b) Study of perkinsinosis in the carpet shell clam Tapes decussatus in Galicia (NW Spain). I. Identification of the aetiological agent and in vitro modulation of zoosporulation by temperature and salinity. Dis Aquat Org 50:51-65

Coss CA, Robledo JAF, Ruiz GM, Vasta GR (2001) Description of Perkinsus andrewsi n. sp. isolated from the Baltic Clam (Macoma balthica) by characterization of the ribosomal RNA locus, and development of species-specific PCR based diagnostic assay. J Eukaryot Microbiol 48:52-61

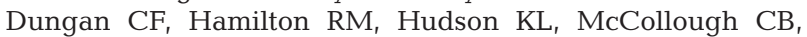
Reece KS (2002) Two epizootic diseases in Chesapeake Bay commercial clams, Mya arenaria and Tagelus plebeius. Dis Aquat Org 50:67-78

Elston R (1986) Occurrence of branchial rickettsiales-like infections in two bivalve molluscs, Tapes japonica and Patinopecten yessoensis, with comments on their significance. J Fish Dis 9:69-71

Goggin CL (1994) Variation in the two internal transcribed spacers and 5.8S ribosomal RNA from five isolates of the marine parasite Perkinsus (Protista, Apicomplexa). Mol Biochem Parasitol 65:179-182

Goggin CL, Lester RJG (1987) Occurrence of Perkinsus species (Protozoa, Apicomplexa) in bivalves from the Great Barrier Reef. Dis Aquat Org 3:113-117

Goggin CL, McGladdery SE, Whyte SK, Cawthorn RJ (1996) An assessment of lesions in bay scallops Argopecten irradians attributed to Perkinsus karlssoni (Protozoa, Apicomplexa). Dis Aquat Org 24:77-80

Hamaguchi M, Suzuki N, Usuki H, Ishioka H (1998) Perkinsus protozoan infection in short-necked clam Tapes (=Ruditapes) philippinarum in Japan. Fish Pathol 33:473-480

Kotob SI, McLaughlin SM, Van Berkum P, Faisal M (1999) Discrimination between two Perkinsus spp. isolated from the softshell clam, Mya arenaria, by sequence analysis of two internal transcribed spacer regions and the 5.8S ribosomal RNA gene. Parasitology 19:363-368

Lauckner G (1983) Diseases of mollusca: Bivalvia. In: Kinne O (ed) Diseases of marine animals, Vol II. Biologische Anstalt Helgoland, Hamburg, p 467-1038

Lester RJG, Davis GHG (1981) A new Perkinsus species (Api- 
complexa, Perkinsea) from the abalone Haliotis ruber. J Invertebr Pathol 37:181-187

Mackin JG, Owen HM, Collier A (1950) Preliminary note on the occurrence of a new protistan parasite, Dermocystidium marinum n. sp. in Crassostrea virginica (Gmelin). Science 111:328

McGladdery SE, Cawthorn RJ, Bradford BC (1991) Perkinsus karlssoni n. sp. (Apicomplexa) in bay scallops Argopecten irradians. Dis Aquat Org 10:127-137

McLaughlin SM, Tall BD, Shaheen A, Elsayed EE, Faisal M (2000) Zoosporulation of a new Perkinsus species from the gills of the softshell clam Mya arenaria. Parasite 7:115-122

Morado JF, Sparks AK, Reed SK (1984) A coccidian infection of the kidney of the native littleneck clam, Protothaca staminea. J Invertebr Pathol 43:207-217

Murrell A, Kleeman SN, Barker SC, Lester RJG (2002) Synonymy of Perkinsus olseni Lester \& Davis, 1981 and Perkinsus atlanticus Azevedo, 1989 and an update on the phylogenetic position of the genus Perkinsus. Bull Eur Assoc Fish Pathol 22:258-265

Editorial responsibility: Albert Sparks, Seattle, Washington, USA
Robledo JA, Wright AC, Marsh AG, Vasta GR (1999) Nucleotide sequence variability in the nontranscribed spacer of the rRNA locus in the oyster parasite Perkinsus marinus. J Parasitol 85:650-656

Robledo JA, Coss CA, Vasta GR (2000) Characterization of the ribosomal RNA locus of Perkinsus atlanticus and development of a polymerase chain reaction-based diagnostic assay. J Parasitol 86:972-978

Scarabino V (1977) Moluscos del Golfo San Matías (Provincia de Río Negro, República Argentina). Inventario y claves para su identificación. Com Soc Malac Urug 4: $177-285$

Thompson JD, GibsonTJ, Plewniak F, Jeanmougin F, Higgins DG (1997) The ClustalX windows interface: flexible strategies for multiple sequence alignment aided by quality analysis tools. Nucleic Acids Res 24:4876-4882

Villalba A, Carballal MJ, López C, Cabada A, Corral L, Azevedo C (1999) Branchial rickettsia-like infection associated with clam Venerupis rhomboides mortality. Dis Aquat Org 36:53-60

Submitted: December 12, 2003; Accepted: October 9, 2004 Proofs received from author(s): February 15, 2005 